\title{
PEREMPUAN DALAM PERSIDANGAN; Kasus Cerai Gugat di Pengadilan Agama Pamekasan.
}

\author{
Oleh: Siti Musawwamah
}

\begin{abstract}
Abstrak:
Artikel ini merupakan hasil penelitian tentang "Realitas Perjuangan" kaum perempuan dalam persidangan kasus cerai gugat di Pengadilan Agama Pamekasan. Cerai gugat sesungguhnya merupakan alternatif dari berbagai pilihan yang dilakukan oleh istri sebagai suatu keputusan untuk mencari solusi dari kemelut problem kerumahtanggaan yang rumit dan memuncak. Dalam perspektif keadilan dan kesetaraan jender putusan cerai gugat di Pengadilan Agama Pamekasan belum merefleksikan keadilan bagi bekas istri karena ketaatan hakim pada asas "Ultra Petitum Partium" yang berlebihan. Seharusnya secara exofficio dalam memutus perkara percerian hakim mempunyai kewenangan untuk memutus juga hak-hak bekas istri meskipun didalam gugatan cerai hak-hak tersebut tidak dituntut karena hakhak tersebut memang merupakan akibat hukum dari perceraian yang dijamin oleh undang-undang.
\end{abstract}

Kata Kunci: cerai gugat, KHI, hakim, tuntutan.

\section{Pendahuluan}

Perkawinan merupakan sebagian sunnatullah yang berlaku bagi semua makhluk hidup sebagai hasil kreasi dan ketetapan Allah Subhanahu wa Ta'ala. Tidak terkecuali di dalamnya adalah perkawinan insaniyah, anak-cucu Nabi Adam-manusia periode awal di muka bumi-sebagaimana tercantum dalam Al-Quran Surah Ar-Rum/30 Ayat 21 dan Surah Adz-Dzaariyat/51 Ayat 49 (Departemen Agama RI, 1984). 


\section{Siti Musawwamah}

Dalam praksis perkawinan manusia terdapat pesan-pesan suci ilahiyah yang menjadi keniscayaan suatu kehidupan, yaitu (a) berkehidupan bersama dalam cinta kasih, (b) berpasang-pasangan dengan makhluk hidup sejenis yang berlainan kelamin, (c) berketurunan atau berkembang biak, (d) saling membantu dalam kebersamaan, (e) hidup dalam suasana harmony, equity, equality, dan equilibrium, (f) berbagi tugas dan fungsi, wewenang dan tanggung jawab, serta kewajiban dan hak individual dalam kolektivitas, dan (g) saling mengisi-joint with giving and receiving together-dalam melakukan berbagai aktivitas, seperti tertera dalam Al-Quran Surah Yaasiin/36 Ayat 36, AnNisaa' / 4 Ayat 34, dan An-Nahl/16 Ayat 72 (Departemen Agama RI, 1984).

Pesan-pesan suci perkawinan itu mengarah pada terwujudnya kehidupan berkeluarga (rumah tangga) yang sakinah, mawaddah, wa rahmah dalam ikatan lahir batin yang kokoh, kuat, dan berbobot (mitsqan ghalidhan). Pesan demikian dinyatakan dalam Al-Quran Surah Ar-Rum/30 Ayat 21 dan An-Nisaa'/4 Ayat 21 (Departemen Agama RI, 1984). Oleh karena itu dapat dinyatakan bahwa perkawinan itu merupakan keniscayaan insaniyah dalam berkehidupan, sebagai bagian dari ketentuan Allah (sunnatullah) yang harus dilaksanakan dan dipelihara keberlangsungannya oleh masingmasing individu manusia.

Dalam realitas kehidupan sehari-hari, tidak semua orang mampu memahami, memaknai, menghayati, dan mengaktualisasikan pesan-pesan suci perkawinan itu sebagai suatu sunnatullah yang harus senantiasa dijaga keberlangsungannya. Peristiwa kesalahpahaman, ketersinggungan, percek-cokan, pertengkaran, pemukulan, dan keke-rasan fisik maupun psikis dalam rumah tangga merupakan sebagian contoh pemicu problem kemelut kerumahtanggaan yang kerapkali dapat mengantar kehidupan suami istri pada perusakan tatanan perka-winan sebagai sunnatullah. Bentuk konkret "perusakan sunnatullah" itu adalah perilaku suami istri yang saling tuduh, saling menyalahkan, saling membalas kemarahan, saling menghina, dan saling menyakiti yang kemudian dapat berlanjut pada gugatan perceraian untuk memutus dan membubarkan ikatan suci perkawinan itu.

Gugatan perceraian sesungguhnya merupakan alternatif dari berbagai pilihan yang dilakukan oleh suami istri sebagai suatu 


\section{PEREMPUAN DALAM PERSIDANGAN; Kasus Cerai Gugat di Pengadilan Agama Pamekasan}

keputu-san untuk mencari solusi dari kemelut problem kerumahtanggaan yang rumit dan memuncak. Gugatan perceraian atas prakarsa suami diistilahkan dengan cerai talak; sedangkan gugatan perceraian atas kehendak istri disebut dengan cerai gugat.

Dalam Laporan Tahunan Pengadilan Agama Pamekasan disebutkan bahwa pada tahun 2004 terdapat 604 perkara yang diajukan oleh masyarakat untuk disele-saikan melalui peradilan agama. $51 \%$ di antaranya adalah perkara cerai talak dan $46 \%$ adalah perkara cerai gugat. Dalam istilah lain, 97\% perkara yang diterima untuk ditangani oleh pengadilan agama didominasi oleh persoalan perceraian sebagai kemelut problem kerumahtanggaan. 3\% sisanya merupakan perkara permohonan/ penetapan. Secara ringkas, laporan tahunan itu diungkapkan pada tabel berikut ini:

Tabel 1 Laporan Tahunan tentang Perkara yang diterima Pengadilan Agama Pamekasan Tahun 2004.

\begin{tabular}{clcc}
\hline No. & $\begin{array}{c}\text { Jenis Perkara yang } \\
\text { Diajukan Masyarakat }\end{array}$ & $\begin{array}{c}\text { Jumlah Pengajuan } \\
\text { Perkara }\end{array}$ & $\begin{array}{c}\text { Persentase } \\
\text { Perkara }\end{array}$ \\
\hline 1. & Ijin Poligami & 3 & $0.5 \%$ \\
2. & Cerai Talak & 308 & $51 \%$ \\
3. & Cerai Gugat & 278 & $46 \%$ \\
4. & Harta Bersama & 1 & $0.2 \%$ \\
5. Itsbat Nikah & 8 & $1.3 \%$ \\
6. Wali Adhal & 5 & $0.8 \%$ \\
7. & Kewarisan & 1 & $0.2 \%$ \\
Jumlah perkara keseluruhan & 604 & $100 \%$ \\
\hline
\end{tabular}

Sumber: Adaptasi data dari Departemen Kehakiman RI (2004).

Sajian laporan tahunan tersebut memberi gambaran yang cukup memprihatinkan betapa kemelut problem kerumahtanggaan pasangan suami istri di Pamekasan secara kuantitas tergolong sangat tinggi (97\%) dan harus diakhiri dengan pemutusan ikatan perkawinan berupa cerai talak maupun cerai gugat.

Kondisi yang cukup merisaukan ini merupakan alasan utama penelitian ini dilakukan. Dalam istilah lain, penelitian ini dilakukan untuk mengetahui bahwa pemahaman, pemaknaan, penghayatan, dan aktualisasi pesan-pesan suci perkawin-an itu belum sepenuhnya 


\section{Siti Musawwamah}

internalized dalam pribadi mereka sebagai suatu sunnatullah yang harus dipelihara keberlangsungannya.

Dari sajian laporan tahunan tersebut juga terdapat perkara perceraian yang menarik untuk diperhatikan. Kaum istri menampakkan keberanian extraordinary (luar biasa) untuk "memecat" atau "memberhentikan tidak secara hormat" status pasangan hidupnya sebagai suami dan kepala rumah tangga, kendati pun telah jamak diketahui umum bahwa mereka sudah dikaruniai puteraputeri hasil perkawinan yang sah. Mereka sangat berani untuk memutus hubungan lahir-batin dalam ikatan sakral yang sengaja telah dijalin bersama dengan kukuh (mitsaqan ghalidhan).

Secara konkrit dan operasional penelitian ini bertujuan untuk (1) Mengidentifikasi secara eksploratif alasan-alasan yang melatarbelakangi pengajuan perkara cerai gugat di Pengadilan Agama Pamekasan, (2) Mendeskripsikan materi tuntutan perkara cerai gugat yang lazim diajukan di Pengadilan Agama Pamekasan, dan (3) Menganalisis putusan cerai gugat berdasarkan standar nilainilai keadilan dan kesetaraan jender.

Temuan-temuan hasil penelitian ini nantinya diharapkan dapat memberi nilai manfaat dalam bentuk kecerahan pola pikir dan wawasan tentang sebagian problem-problem kritis dan krisis kemasyarakatan khususnya bagi praktisi hukum, pemimpin umat dalam komunitasnya, dan pengambil keputusan institusional. Nilai manfaat itu juga diharapkan dapat dipetik oleh para akademisi pengkaji dan penyebar informasi keilmuan serta para peneliti dan pemerhati problem-problem sosioyuridis sebagai bahan untuk ikutserta memperbaiki tatanan kehidupan dalam pergaulan sosial.

\section{Metode Penelitian}

Penelitian ini menggunakan pendekatan hukum normatif (normative-law jurisprudence approach) dengan jenis penelitian evaluative ex-post facto atas problema pengajuan perkara, proses persidangan, dan produk putusan perkara cerai gugat yang telah diselesaikan oleh Pengadilan Agama. Pilihan pendekatan ini dipandang sesuai karena bahan hukum primer pada kajian utama penelitian ini adalah dokumen-dokumen hukum tertulis (Noeng Muhadjir, 1989; Soejono \& Abdurrahman, 2003; Amiruddin \& Zainal Asikin, 2004), berupa 


\section{PEREMPUAN DALAM PERSIDANGAN; Kasus Cerai Gugat di Pengadilan Agama Pamekasan}

sejumlah produk putusan hakim tentang cerai gugat, arsip pengajuan perkara, statistik perkara yang diterima dan diputus pengadian, dan laporan tahunan yang diterbitkan oleh Pengadilan Agama Pamekasan (Departemen Kehakiman RI, 2004). Dengan kata lain, penelitian ini dapat juga diistilahkan sebagai kajian isi yurisprudensi (jurisprudential content study) sebagai pendekatan utamanya (Soerjono Soekanto, 1986; Soejono \& Abdurrahman, 2003).

Penetapan evaluative ex-post facto research sebagai jenis penelitian yang dipilih dalam kajian ini dipandang relevan digunakan berdasarkaln argumentasi antara lain, yaitu (a) penelitian ini dilakukan untuk mengkaji dan mengevaluasi fakta hukum yang telah terjadi pada masa penelitian ini dilaksanakan, yaitu pada tahun 20032004, (b) peneliti tidak melakukan treatment apapun atas fakta dan data yang dikaji karena peristiwanya telah berlangsung, (c) peneliti mengevaluasi kinerja majelis hakim dalam penerapan norma hukum, kaidah-kaidah hukum, dan aturan perundang-undangan yang menjadi pertimbangan dan landasan hukum majelis dalam memutus perkara pada dokumen yang telah diterbitkan, dan (d) peneliti memeriksa kesesuaian antara dokumen putusan hakim dengan kenyataan dan rasa keadilan subjek hukum dalam perspektif akademik.

Penelitian ini menggunakan orientasi teoretik verstehen paradigm, yaitu suatu perspektif subjektif tentang pengertian interpretatif atas pemahaman fakta, makna, peristiwa dan keterkaitannya dalam situasi tertentu, termasuk di dalamnya adalah produk pikiran manusia dalam bentuk tertulis (Moleong, 1990).

Telaah atas makna dan pemahaman interpretatif subjek penelitian pada produk putusan cerai gugat oleh Pengadilan Agama, dengan demikian dapat mewadahi penelitian ini sesuai dengan perspektif teoretik verstehen paradigm. Pemahaman atas makna teks tertulis itu menjadi kajian pokok penelitian ini.

Data penelitian ini dihimpun dari sumber data sekunder yang meliputi produk putusan hakim tentang cerai gugat, arsip pengajuan perkara, statistik perkara yang diterima dan diputus pengadian, dan laporan tahunan yang diterbitkan oleh Pengadilan Agama.

Sejalan dengan desain penelitian ini, data dikumpulkan dengan metode noninteraktif, yaitu pengumpulan data diarahkan pada akumulasi isi dokumen, arsip, maupun data statistik tentang 


\section{Siti Musawwamah}

perkara cerai gugat yang tersedia dan/atau diterbitkan oleh pengadilan Agama. Data dokumentasi yang menjadi fokus perhatian utama adalah sejumlah produk putusan majelis hakim tentang perkara cerai gugat yang telah memiliki kekuatan hukum tetap pada tahun 2004 yang diambil secra acak tiap bulan 2 perkara, sedangkan dokumen lainnya diperlakukan sebagai pendukung atau penguat data tentang produk putusan. (Denzin \& Lincoln, 1994; Yin, 1996)

Penggunaan teknik observasi dalam bentuk pengamatan secara terlibat (participative observation), sebagai bagian dari kegiatan pengumpulan data, tidak digunakan dalam penelitian ini, karena peristiwa hukum dalam perkara cerai gugat itu telah terjadi pada masa penelitian dini dilakukan. Oleh karena itu penggunaan teknik observasi dipandang tidak relevan disebabkan penelitian ini tergolong sebagai pengungkapan fakta dan data yang telah terjadi ( $e x-$ post facto research) (Sugiyono, 1997).

Data penelitian yang berhasil dikumpulkan kemudian dianalisis dengan menggunakan teknik content analysis pada dokumen utama dan dokumen penunjang. Analisis ini dilakukan melalui proses pelacakan dan pengaturan secara sistematik atas tematema konseptual dan indikator yang menjadi fokus perhatian penelitian yang terdapat dalam dokumen (Kerlinger, 1973; Babbie, 1986; Young, 1982; Hadari Nawawi, 1983; Moleong, 1990).

Data yang telah berhasil dihimpun kemudian diinterpretasi sebagai temuan hasil penelitian. Terhadap temuan tersebut dilakukan teknik keabsahan data melalui teknik pembahasan sejawat, analisis kasus negatif, dan pelacakan kesesuaian data (Goetz \& LeCompte, 1991).

\section{Hasil Penelitian}

\section{Latar Belakang Pengajuan Cerai Gugat}

Pengajuan Cerai Gugat di Pengadilan Agama Pamekasan karena adanya alasan terkait dengan kekerasan dalam rumah tangga (KDRT) dalam bentuk-bentuk: kekerasan fisik, kekerasan psikis, kekerasan ekonomik dan penelantaraan rumah tangga.

a. Kekerasan Fisik 


\section{PEREMPUAN DALAM PERSIDANGAN; Kasus Cerai Gugat di Pengadilan Agama Pamekasan}

Kekerasan fisik yang dilakukan oleh suami kepada istrinya pada umumnya bukanlah perilaku menyimpang yang berdiri sendiri tetapi seringkali merupakan gabungan atau akumulasi dari beberapa bentuk kekerasan yang lain. Berikut ini adalah 2 contoh petikan putusannya:

1) Putusan Perkara Nomor: 172/Pdt.G/2004/PA.Pmk.

Perkara ini terjadi antara Penggugat berusia 26 tahun pekerjaan tani dengan Tergugat berusia 28 tahun pekerjaan tani. Setelah perkawinan berusia 2 tahun Penggugat mengajukan cerai gugat karena Tergugat sering memukul jika ditegur karena lalai memenuhi kewajiban memberi nafkah dan sering keluyuran.

2). Putusan Perkara Nomor: 101/Pdt.G/2004/PA.Pmk.

Perkara ini terjadi antara Penggugat berusia 46 tahun pekerjaan guru SMP dengan Tergugat berusia 40 tahun pekerjaan wiraswasta. Setelah perkawinan berusia 13 tahun Penggugat mengajukan cerai gugat karena Tergugat sering memukul jika sedang bertengkar

b. Kekerasan Psikis

Hampir sama dengan kekerasan fisik, kekerasan psikis yang dilakukan suami kepada istri ada yang berdiri sendiri dan ada juga yang merupakan gabungan dari beberapa bentuk kekerasan. Diantaranya: tuduhan selingkuh tanpa bukti, kecemburuan yang berlebihan dan perjodohan paksa. Berikut ini adalah 2 contoh petikan putusannya:

1). Putusan Perkara Nomor: 511/Pdt.G/2004/PA.Pmk

Perkara ini terjadi antara Penggugat berusia 32 tahun pekerjaan dosen dengan Tergugat berusia 33 tahun tidak punya pekerjaan. Setelah perkawinan berusia 11 tahun Penggugat mengajukan cerai gugat karena sering terjadi perselisihan dan pertengkaran. Penyebabnya adalah karena Tergugat sering cemburu kepada setiap mahasiswa yang datang ke rumah untuk konsultasi bahkan kepada setiap laki-laki yang berhubungan dengan Penggugat. Akhirnya Tergugat pamit pergi dan tidak ada kabar.

2). Putusan Perkara Nomor: 86/Pdt.G/2004/PA.Pmk

Perkara ini terjadi antara Penggugat berusia 28 tahun pekerjaan tani dengan Tergugat berusia 28 tahun pekerjaan tani. Setelah perkawinan berusia 5 bulan Penggugat mengajukan cerai gugat karena sering terjadi perselisihan dan pertengkaran. Penyebabnya 


\section{Siti Musawwamah}

adalah karena Perkawinan Penggugat dan Tergugat tidak berdasar rasa saling mencintai karena dijodohkan oleh orang tua masing-masing.

\section{c. Kekerasan Ekonomik}

Dalam penelitian ini kekerasan ekonomik yang dilakukan suami kepada istri juga dikuti oleh beberapa bentuk kekerasan lain. Mulai dari ketidakmampuan suami memenuhi kebutuhan rumah tangga, pemborosan uang keluarga sampai pada main perempuan dan bahkan kawin secara diam-diam. Berikut ini adalah 2 contoh petikan putusannya:

1). Putusan Perkara Nomor: 474/Pdt.G/2004/PA.Pmk

Perkara ini terjadi antara Penggugat berusia 34 tahun pekerjaan ibu rumah tangga dengan Tergugat berusia 41 tahun pekerjaan wiraswasta. Setelah perkawinan berusia 13 tahun Penggugat mengajukan cerai gugat karena sering terjadi perselisihan dan pertengkaran. Penyebabnya adalah karena Tergugat tidak mampu memenuhi nafkah keluarga sehingga untuk memenuhi kebutuhan rumah tangga Penggugat berhutang kepada orang lain. Karena dililit banyak hutang dan Tergugat tidak ada upaya apa-apa, maka dengan memalsukan identitas Penggugat bisa lolos menjadi Tenaga Kerja Wanita (TKW) ke Taiwan. Selama berada di Taiwan uang penghasilan Penggugat kirim ke Tergugat dengan tujuan untuh melunasi hutang. Tetapi, uang tersebut justru dihabiskan dan Tergugat malah bertunangan dengan sepupunya sendiri. Setelah Penggugat pulang kembali ke Madura, Tergugat tidak ada niat untuk memperbaiki diri dan minta maaf kepada Penggugat.

2). Putusan Perkara Nomor: 542/Pdt.G/2004/PA.Pmk

Perkara ini terjadi antara Penggugat berusia 55 tahun pekerjaan ibu rumah tangga dengan Tergugat berusia 58 tahun pekerjaan wiraswasta. Setelah perkawinan berusia 23 tahun Penggugat mengajukan cerai gugat karena sering terjadi perselisihan dan pertengkaran. Penyebabnya adalah Penggugat (atas izin Tergugat) pergi ke Arab Saudi untuk bekerja sebagai Tenaga Kerja Wanita (TKW). Selama 4 tahun berada di Arab Saudi sebagian uang penghasilan berjumlah $+/-40$ juta Penggugat kirim 


\section{PEREMPUAN DALAM PERSIDANGAN; Kasus Cerai Gugat di Pengadilan Agama Pamekasan}

ke Tergugat Tetapi, setelah Penggugat pulang kembali ke Madura uang tersebut justru dihabiskan Tergugat untuk main perempuan. Akibatnya Tergugat pulang ke rumah orang tuanya dan Penggugat kembali lagi ke Arab Saudi untuk bekerja. Setelah 3 tahun berada di Arab Saudi Penggugat pulang kembali ke Madura dan Tergugat telah berada serumah dengan istri mudanya.

D. Penelantaran Rumah Tangga

Penelantaran rumah tangga yang menjadi alasan cerai gugat pada penelitian ini adalah bukti ketidakmampuan suami melaksanakan tanggungjawab sebagai suami dan atau kepala keluarga. Berikut ini adalah 2 contoh petikan putusannya:

1). Putusan Perkara Nomor: 11/Pdt.G/2004/PA.Pmk

Perkara ini terjadi antara Penggugat berusia 31 tahun pekerjaan tani dengan Tergugat berusia 31 tahun pekerjaan wiraswasta. Setelah perkawinan berusia 8 tahun Penggugat mengajukan cerai gugat karena sering terjadi perselisihan dan pertengkaran. Penyebabnya adalah karena Tergugat meninggalkan Penggugat di Jakarta saat akan bekerja ke Sumatra. Setelah Penggugat pulang kembali ke Madura Tergugat tidak mau menemui Penggugat.

2). Putusan Perkara Nomor: 243/Pdt.G/2004/PA.Pmk

Perkara ini terjadi antara Penggugat berusia 27 tahun pekerjaan tani dengan Tergugat berusia 34 tahun pekerjaan tani. Setelah perkawinan berusia 10 tahun Penggugat mengajukan cerai gugat karena Tergugat pergi bekerja ke Malaysia sampai 8 tahun tidak ada kabar dan tidak mengirimkan nafkah.

\section{Materi Tuntutan Cerai Gugat}

Dari 24 kasus cerai gugat yang menjadi subyek penelitian ini hanya ada satu kasus dimana istri juga menggugat hak penguasaan atau hak perwalian terhadap anaknya. Selebihnya bekas istri tidak menuntut hak-haknya kepada bekas suaminya. Pada umumnya gugatan cerai dari istri Petitumnya hanya memuat hal-hal berikut ini: Petitum Primer:

1. Mengabulkan gugatan Penggugat;

2. Menceraikan Perkawinan antara Penggugat dan Tergugat 


\section{Siti Musawwamah}

3. Menetapkan biaya perkara ini menurut hukum Petitum Subsider:

Apabila Pengadilan Agama berpendapat lain, mohon putusan yang seadil adilnya.

Dilihat dari petitum gugatan cerai tersebut, istri tidak menyatakan atau menggabungkan tuntutan tentang penguasaan anak, nafkah anak dan istri serta pemeliharaan atau pembagian harta bersama dalam gugatan pokok meskipun menurut pasal 86 ayat 1 Undang-undang Nomor 7 Tahun 1989 tentang Peradilan Agama (selanjutnya disebut UU No.7/1989\}bagi istri diberi hak untuk mengakumulasikan tuntutan haknya bersama-sama dengan gugatan perceraian. Sebenarnya ada beberapa keuntungan penggabungan tuntutan hak istri dengan gugatan pokok, yaitu dapat menghemat waktu dan biaya serta dapat menghindari keputusan yang saling bertentangan.

Ada beberapa hal yang menjadi alasan para istri tidak menggabungkan hak-haknya dalam tuntutan pokoknya sebagai berikut:

1. Bekas istri tidak mungkin menuntut hak-haknya kepada bekas suami karena bekas suami tidak bekerja;

2. Bekas istri tidak mungkin menuntut hak-haknya kepada bekas suaminya karena sejak akad nikah berlangsung belum pernah terjadi hubungan layaknya suami istri. Ini terjadi pada pasangan suami istri yang perkawinannya dipaksakan;

3. Tidak ada harta yang bisa dibagi karena semua harta sudah dihabiskan oleh bekas suami. Ini terjadi pada bekas istri yang bekerja menjadi TKW penghasilannya dihabiskan bekas suami untuk main perempuan;

4. Bekas istri bekerja sehingga penghasilannya bisa untuk memenuhi semua kebutuhan keluarga;

5. Bagi bekas istri yang terpenting adalah bisa bercerai dari bekas suami. Ini terjadi pada bekas istri yang terjerat problem kerumahtanggaan yang berkepanjangan. 


\section{PEREMPUAN DALAM PERSIDANGAN; Kasus Cerai Gugat di Pengadilan Agama Pamekasan}

Seperti telah dijelaskan sebelumnya, dalam penelitian ini peneliti hanya menemukan satu kasus istri mengajukan hak-haknya bersamaan dengan pengajuan gugatan pokok yaitu hak penguasaan atau perwalian terhadap anak dan dikabulkan oleh majelis hakim. Berikut ini adalah petikan putusannya, Putusan Nomor: 101/Pdt.G/2004/PA.Pmk

Petitum Primer:

1. Mengabulkan gugatan Penggugat

2. Menceraikan Perkawinan antara Penggugat dan Tergugat

3. Menetapkan hak perwalian anak bernama Shintabela (bukan nama sebenarnya) kepada Penggugat

4. Menetapkan biaya perkara ini menurut hukum

Petitum Subsider:

Apabila Pengadilan Agama berpendapat lain, mohon putusan yang seadil-adilnya.

Dalam Petitum Primer tersebut, istri hanya mengajukan tuntutan hak pengasuhan atau perwalian terhadap anak tidak mengajukan tuntutan hak-hak yang lain. Padahal, menurut pasal 78 UU No.7/1989 suami maupun istri selama berlangsungnya gugatan perceraian dapat memohon kepada Pengadilan Agama untuk menentukan nafkah dan hal-hal lain yang perlu untuk menjamin terpeliharanya barang-barang yang menjadi hak bersama suami istri atau barang-barang yang sudah menjadi hak suami atau istri.

Setelah membaca dan menganalisis berkas putusan cerai gugat tersebut secara cermat, dapat dikemukakan beberapa hal yang mungkin menjadi alasan istri tidak menggabungkan seluruh hakhaknya dalam tuntutan pokoknya sebagai berikut:

1. Beberapa hak istri yang tidak dituntut dalam gugatan pokok sudah dapat diselesaikan secara kekeluargaan di luar sidang pengadilan.

2. Bekas istri akan mengajukan hak-haknya secara terpisah dari gugatan pokok setelah adanya putusan perceraian.

\section{Analisis Putusan Berdasarkan Keadilan Dan Kesetaraan Jender}




\section{Siti Musawwamah}

a. Pertimbangan Hukum yang Mendasari Putusan Hakim

Pertimbangan hukum adalah pendapat hakim tentang suatu perkara dengan disertai alasan-alasan dan dasar hukumnya. Secara terperinci pertimbangan hukum berisi hal-hal sebagai berikut:

1. Gambaran tentang bagaimana hakim mengkwalifisir fakta atau kejadian

2. Penilaian hakim tentang fakta-fakta yang diajukan

3. Hakim mempertimbangkannya secara kronologis dan rinci setiap item, baik dari pihak Penggugat maupun Tergugat

4. Memuat dasar-dasar hukum yang dipergunakan oleh hakim dalam menilai fakta dan memutus perkara, baik hukum tertulis maupun hukum tidak tertulis

Berikut ini adalah berkas pertimbangan hukum putusan perkara Nomor: 101Pdt.G/2004/PA.Pmk

Menimbang: Bahwa yang menjadi alasan dari gugatan penggugat adalah antara penggugat dan tergugat telah terjadi perselisihan dan pertengkaran karena tergugat sering mengatakan kata-kata cerai kepada pernggugat, sehingga antara penggugat dan tergugat telah terjadi pisah rumah selama 1 (satu) bulan;

Menimbang: bahwa tergugat dalam jawabannya mengakui telah pisah rumah hingga kini telah 3 bulan, karena tergugat sering mengatakan kata-kata cerai dan marah sekali pun hal itu di luar kesadaran tergugat.

Menimbang: Bahwa saksi-saksi penggugat menerangkan bahwa penggugat dan tergugat telah bertengkar sehingga penggugat dan tergugat pisah rumah hingga kini +/3 bulan.

Menimbang: Bahwa majelis hakim telah berusaha untuk merukunkan kembali penggugat dan tergugat demikian juga pihak keluarga namun tidak berhasil. 
PEREMPUAN DALAM PERSIDANGAN; Kasus Cerai Gugat di Pengadilan Agama Pamekasan

Menimbang: Bahwa oleh karena usaha-usaha untuk mendamaikan dan merukunkan kembali penggugat dan tergugat tidak berhasil maka majelis hakim berpendapat bahwa dalam rumah tangga penggugat dan tergugat sudah tidak ada saling cinta mencintai, hormatmenghormati, setia, dan memberi bantuan lahir batin yang satu kepada yang lain (Vide Pasal 33 UU No. 1/1974) dan telah tidak pula tercapat tujuan perkawinan yang membentuk rumah tangga yang bahagia dan kekal berdasarkan ketuhanan yang Maha Esa (Vide Pasal 1 UU No. 1/1974) sehingga ada alasan hukum untuk tidak mempertahankan perkawinan penggugat dengan tergugat dan bahkan dibenarkan untuk melepaskan ikatan perkawinan antara keduanya.

Menimbang: Bahwa oleh karena penggugat sudah sangat tidak suka kepada tergugat maka hakim dapat menjatuhkan talak 1 tergugat kepada penggugat, sesuai dengan dalil (dikutip dari Himpunan Nash dan Hujjah Syar'iyah Putusan/Penetapan Pengadilan Agama, Proyek Pembinaan Badan Peradilan Agama, Departemen Agama 1976 hlm 47) yang artinya: di waktu istri dalam kondisi telah memuncak kebencian terhadap suaminya, maka hakim dapat diperkenankan menjatuhkan talak suaminya itu dengan talak.

Menimbang: Bahwa berdasarkan pertimbangan-pertimbangan tersebut di atas, maka gugatan penggugat dipandang telah mempunyai cukup alasan dan telah memenuhi ketentuan Pasal 19 huruf (f) PP No. 9/1975 jo. Pasal 116 huruf (f) KHI; Oleh karena itu gugatan penggugat sepatutnya dikabulkan. 


\section{Siti Musawwamah}

Menimbang: Bahwa gugatan penggugat agar ditetapkan sebagai pemegang hak hadhanah atau hak pemeliharaan anak, majelis hakim dapat mengabulkan karena anak yang bernama Shinta, umur 8 Tahun tersebut belum mumayyiz (atau kurang dari 12 tahun) karena anak yang belum mumayyiz adalah hak ibunya untuk memeliharan anak tersebut. Sedangkan anak yang telah mumayyiz terserah anak itu untuk memilih di antara ayah atau ibunya sebagai pemeganga hak pemeliharaan anak. Hal ini sesuai dengan pasal 105 huruf (a) KHI dan dalil Fiqih yang tercantum dalam I'anah ath-thalibin Juz IV hal 101-107, yang artinya diutamakan mengurus anak yang belum mumayyiz ialah ibunya yang janda dan kalau sudah mumayyiz dan ibu bapaknya sudah bercerai makan dia boleh tinggal di pihak mana yang ia suka.

Menimbang. Bahwa berdasarkan ketentuan Pasal 98 Ayat 1 UU No. 7/1989 maka biaya perkara dibebankan kepada penggugat. Mengingat segala ketentuan per-UU-an yang berlaku dan hukum syar'I yang berkaitan dengan perkara ini.

Paparan berkas pertimbangan hukum yang diterapkan oleh majelis hakim peradilan agama tersebut baru memenuhi ketentuan bunyi teks Undang-undang atau peraturan hukum belum memenuhi kepatutan manusiawi, proporsi hak dan kewajiban serta inisiatif majelis hakim atas tuntutan kemaslahatan.

b. Justifikasi Keadilan dan Kesetaraan jender

Sebagai salah satu lembaga pelaksana kekuasaan kehakiman Pengadilan Agama mempunyai tugas pokok untuk menerima, memeriksa dan mengadili serta menyelesaikan setiap perkara yang diajukan kepadanya guna menegakkan hukum dan keadilan berdasarkan Panasila demi terselenggaranya negara hukum Republik 
PEREMPUAN DALAM PERSIDANGAN; Kasus Cerai Gugat di Pengadilan Agama Pamekasan

Indonesia (pasal 1 dan 2 UU No.14/1970). Oleh karena itu, setiap penetapan atau putusan Pengadilan Agama harus berkepala Bismillahirrahmanirrahim Dan Demi Keadilan Berdasarkan

Ketuhanan Yang Maha Esa (pasal 57 UU No.7/1989)

Ketentuan tersebut menjadi dasar bahwa keadilan yang seharusnya diberikan kepada pencari kebenaran dan keadilan yang menjadi intisari penegakan hukum adalah keadaan yang dapat dipertanggungjawabkan di hadapan Allah SWT atau keadilan yang berdasar Ketuhananan Yang Maha Esa. Keadilan seperti inilah yang seharusnya direfleksikan oleh setiap badan peradilan dan untuk itu diperlukan adanya keberanian hakim untuk menegakkan hukum sebagai refleksi kebenaran dan keadilan.

Hukum memang tidak dapat berdiri sendiri, tetapi harus ditegakkan oleh aparat hukum. Salah satu cara penegakan hukum adalah melalui penafsiran perundang-undangan yang berlaku sehubungan dengan perkara yang sedang ditangani. Bahkan jika diperlukan dalam memutuskan perkara hakim tidak cukup hanya memegangi ajaran hukum positif yang yang membatasi diri pada law as it is written in the book (Soetandyo, 2000:190) tetapi juga didasari oleh pemikiran yang seimbang dan bijaksana antara hukum dan etika Contoh berkas putusan Nomor: 101Pdt.G/2004/PA.Pmk

Petitum Primer:

1. Mengabulkan gugatan Penggugat

2. Menceraikan perkawinan antara Penggugat dan Tergugat

3. Menetapkan hak perwalian terhadap anak bernama Shinta (bukan nama sebenarnya) kepada Penggugat

4. Menetapkan biaya perkara menurut hukum

Petitum Subsider:

Atau mohon putusan yang seadil-adilnya

Diktum putusan:

1. Mengabulkan gugatan Penggugat

2. Menjatuhkan talak satu bain sughra dari Tergugat terhadap Penggugat

3. Menetapkan hak perwalian terhadap anak bernama Shinta (bukan nama sebenarnya) kepada Penggugat

4. Memerintahkan Panitera Pengadilan Agama Pamekasan untuk mengirimkan salinan putusan kepada Pegawai Pencatat Nikah yang wilayahnya meliputi tempat kediaman Penggugat dan 


\section{Siti Musawwamah}

Tergugat dan kepada Pegawai Pencatat Nikah di tempat perkawinan dilangsungkan guna didaftarkan dan dicatat dalam daftar yang disediakan untuk itu

5. Membebankan biaya perkara kepada Penggugat

Jika petikan petitum gugatan dan diktum putusan tersebut dianalisis, maka akan menunjukkan bahwa hakim hanya taat pada satu asas hukum saja, yaitu asas "Ultra Petitum Partium" yang artinya hakim dilarang memutus hal-hal yang tidak dituntut atau mengabulkan hal-hal lebih dari yang dituntut (pasal 178 ayat 3 HIR dan pasal 189 ayat $3 \mathrm{Rbg}$ ) dan mengabaikan asas hukum yang lain.

Sebenarnya asas hukum "Ultra Petitum Partium"itu tidak harus diberlakukan secara mutlak jika saja hakim juga memegangi asas hukum yang lain yang menyatakan bahwa hakim wajib mengadili seluruh petitum yang diajukan dan tidak boleh melebihi dari yang diminta kecuali Undang-undang menentukan lain (pasal 178 HIR, pasal 41 (C) UU No.1/1974 dan pasal 149 KHI)

Kata-kata "kecuali Undang-undang menentukan lain" inilah yang bisa dijadikan dasar untuk menyimpangi asas "Ultra Petitum Partium" asalkan masih ada hubungan satu sama lainnya atau masih sesuai dengan kejadian materiil. Masalah perwalian anak, biaya pemeliharaan anak, nafkah madliyah dan nafkah iddah, serta pembagian harta bersama adalah masalah yang sangat erat dengan perceraian berdasarkan ketentuan berikut ini:

Pasal 41 Ayat [c] UU No.1/1974 mencantumkan bahwa akibat putusnya perkawinan karena perceraian adalah pengadilan mewajibkan kepada bekas suami untuk memberikan biaya penghidupan dan/atau menentukan sesuatu kewajiban bagi bekas istri.

Pasal 105 ayat $3 \mathrm{KHI}$ : Dalam hal terjadi perceraian biaya pemeliharaan anak ditanggung oleh ayahnya jo pasal 41 huruf (b) UU No.1/1974: Akibat putusnya perkawinan karena perceraian adalah bapak yang bertanggungjawab atas semua biaya pemeliharaan dan pendidikan yang diperlukan anak. Bilamana bapak dalam kenyataan tidak dapat memenuhi kewajiban tersebut, pengadilan dapat menentukan bahwa ibu ikut memikul biaya tersebut.

Dalam perspektif keadilan dan kesetaraan jender putusan cerai gugat di Pengadilan Agama Pamekasan belum merefleksikan keadilan bagi bekas istri karena ketaatan hakim pada asas "Ultra 


\section{PEREMPUAN DALAM PERSIDANGAN; Kasus Cerai Gugat di Pengadilan Agama Pamekasan}

Petitum Partium" yang berlebihan. Seharusnya secara exofficio dalam memutus perkara percerian hakim mempunyai kewenangan untuk memutus juga hak-hak bekas istri meskipun didalam gugatan cerai hak-hak tersebut tidak dituntut karena hak-hak tersebut memang merupakan akibat hukum dari perceraian yang dijamin oleh undangundang.

\section{Kesimpulan}

Mengakhiri paparan artikel ini dapat disimpulakan bahwa (1) Latarbelakang pengajuan perkara cerai gugat di Pengadilan Agama Pamekasan menunjukkan bahwa problem kekerasan dalam rumah tangga (KDRT) telah menimpa dan diderita oleh kaum perempuan (istri). Berbagai jenis KDRT yang telah dilakukan para suami dalam bentuk antara lain: kekerasan fisik, kekerasan psikis, kekerasan ekonomik dan penelantaraan rumah tangga sudah sedemikian berat dan tidak tertahankan diderita oleh para istri, (2) Pada umumnya istri tidak menyatakan atau menggabungkan tuntutan tentang hak-haknya dalam gugatan pokoknya meskipun menurut pasal 86 ayat $1 \mathrm{UU}$ No.7/1989 bagi istri diberi hak untuk mengakumulasikan tuntutan haknya bersama-sama dengan gugatan perceraian, (3) Dalam perspektif keadilan dan kesetaraan jender putusan cerai gugat di Pengadilan Agama Pamekasan belum merefleksikan keadilan bagi kaum perempuan bekas istri

Berdasarkan tiga rumusan kesimpulan penelitian tersebut disarankan, khususnya bagi (1) Ketua dan hakim Pengadilan Agama Pamekasan sebagai informasi-balikan (feedback information) tentang kinerja internal majelis hakim, bahan evaluasi, perbaikan performansi, maupun pengambilan berbagai keputusan institusional berkaitan dengan pembinaan para hakim dalam penanganan dan penyelesaian kasus cerai gugat, (2) Para pihak yang mengajukan dan/atau membantu menangani perkara cerai gugat ke Pengadilan Agama, hendaknya memerhatikan pentingnya pencerahan dan pengayaan wawasan yudisial dalam mencermati pelaksanaan proses peradilan hingga terbitnya putusan majelis hakim dalam perkara cerai gugat, serta eksekusi hasil putusannya, (4) Para Cendekiawan Muslim dan Kiai yang berposisi sebagai tokoh atau pemimpin umat 


\section{Siti Musawwamah}

sebagai informasi yang sangat berharga tentang proses dan produk peradilan agama tentang perkara cerai gugat oleh majelis hakim Pengadilan Agama Pamekasan, (5) Para akademisi, peneliti, dan pemerhati problema sosial kemasya-rakatan khususnya dosen-dosen fakultas/jurusan Syariah, agar penelitian ini dapat ditindaklanjuti dalam kegiatan yang lain. 